\title{
Analyzing the Relationship Between Addiction to Video Gaming and Primary Monosymptomatic Nocturnal Enuresis in Children
}

\author{
Parsa Yousefichaijan, ${ }^{1}$ Masoud Rezagholizamenjany, ${ }^{2,}{ }^{*}$ Ali Arjmand, ${ }^{1}$ and Fakhredin Shariatmadari ${ }^{1}$ \\ ${ }^{1}$ School of Medicine, Arak University of Medical Sciences, Amirkabir Hospital, Department of Pediatric Nephrology, Arak, Iran \\ ${ }^{2}$ School of Medicine, Arak University of Medical Sciences, Arak, Iran \\ "Corresponding author: Mr Masoud Rezagholizamenjany, School of Medicine, Arak University of Medical Sciences, Arak, Iran. Tel: +98-9184374727, E-mail: \\ masoudrezagholi074@gmail.com
}

Received 2018 February 14; Accepted 2018 April 24.

\begin{abstract}
Background: Nocturnal enuresis is defined as urinary incontinence in children more than five years of age, who are adequately mature to achieve continence of urination.

Objectives: Aim of this was to study children with primary mono-symptomatic nocturnal enuresis in regards to video gaming addiction.

Methods: In total, 200 children, 100 healthy children as the control group and 100 children with primary mono-symptomatic nocturnal enuresis as the case group, were evaluated. Epidemiologic, video gaming, and nocturnal enuresis information were collected and analyzed by the SPSS software, and significant differences $(\mathrm{P}<0.05)$ were considered.

Results: Children with primary monosymptomatic nocturnal enuresis were more prone to video gaming addiction compared with healthy children $(\mathrm{P}<0.0001)$.

Conclusions: Video gaming addiction has a significant impact on primary monosymptomatic nocturnal, thus control of stressful factors, instead of pharmacotherapy, can reduce this condition as a symptom.
\end{abstract}

Keywords: Primary Monosymptomatic Nocturnal Enuresis, Video Gaming, Addiction, Children

\section{Background}

Primary mono-symptomatic nocturnal enuresis is involuntary urination during night time in children aged five years old and above, who are adequately mature to gain continence of urination, which cannot be attributed to any organic or medication reasons $(1,2)$. This condition is grouped to primary nocturnal enuresis (80\%) and secondary nocturnal enuresis (20\%). Children, who have not gained continence and dryness in the past, are considered to have primary nocturnal enuresis, and incontinence in children, who have had a period of at least six months of continence, is known as secondary nocturnal enuresis (3, 4). Overall, $15 \%$ to $30 \%$ of children older than six years of age, $15 \%$ of children with five years of age, $7 \%$ of children with eight years of age, and $1 \%$ of children with 15 years of age, wet their bed at least one night per month; the odds ratio of nocturnal enuresis is 1.4:1 in males and females (5-7). Etiologies of this condition is multifactorial and not fully understood, yet some causes may be small bladder capacity, chronic constipation, genetic influences (autosomal dominant), delayed acquisition of urination control, de- trusor muscle malfunction, involuntary contractions, effect of psychological and behavioral factors, and delayed functional maturation of the central nervous system (8). Treating any underlying organic causes of enuresis is the first step of treatment $(9,10)$. The most commonly used treatment options are conditioning therapy and pharmacotherapy (11). The clinician can also assist the family in making a plan and helping the child cope with this problem $(12,13)$. Bedwetting alarm, is the most widely used conditioning therapy, with 70\% initial success and 10\% relapse, and desmopressin acetate/tricyclic antidepressants, as pharmacotherapy, is not curative, with $90 \%$ relapse (14, 15). Gaming addiction as an important factor can induce psychological stressful and lead to urination incontinence. There are different points of view in gaming that include societal and scientific arguments about whether the content of video games can lead to a negative behavior and attitudes in the player's normal life, and whether this is reflected in the overall video game industry (16). This addiction can lead to headaches, dizziness, and evens chances of vomiting from focusing on a screen for too long (17, 
18). Based on content, the researchers decided to compare video gaming in children with primary monosymptomatic nocturnal enuresis compared to healthy controls. The aim of this research was to study primary monosymptomatic nocturnal enuresis in children and its correlation with video gaming addiction.

\section{Methods}

\subsection{Study Setting}

Pediatric clinic of Amirkabir hospital, Arak, Iran.

\subsection{Study Population}

This was a case-control study conducted on 200 children, aged five to fifteen years old. Children with primary monosymptomatic nocturnal enuresis and consent to participate in the research project were included in the study yet children, who for any reason wanted to leave the study and were not satisfied with use of their data in the study, were excluded from the study. Children were selected by convenience sampling, from 100 children with primary monosymptomatic nocturnal enuresis as the case group, and 100 healthy children as the control group.

\subsection{Measurements}

Height, weight, and body mass index (BMI) were measured with standard methods. Children and their parents answered the demographic and gaming questionnaires.

\subsection{Ethical Issues}

1 , The research followed the tenets of the declaration of Helsinki; 2, Informed consent was obtained, and the participants were free to leave the study at any time; 3 , The ethical committee approved the research with ethical number of 93-176-16

\subsection{Statistical Analysis}

Data analysis was conducted by independent T-test using the SPSS program and significance level was considered as $\mathrm{P}<0.05$

\section{Results}

In total, this study included 200 children, based on Table $1 ; 61 \%$ were male and $39 \%$ were female $(P=1.0)$. Also according to Table 1 , delivery type $(\mathrm{P}=0.319)$ and gastational age $(P=0.056)$ have not a statistically significant diffrence, and birth wieght $(\mathrm{P}=0.004)$ had statistically significant diffrences in the two groups. As mentioned in Table 2, all aspects of gaming status in the two groups had a significant diffrence $(\mathrm{P}<0.0001)$ and gaming status in the case and control group was $93 \%$ and $68 \%$, respectively. Based on Table 3, familial status, including father's $(\mathrm{P}=0.005)$ and mother's education ( $\mathrm{P}=0.001)$, economical status ( $\mathrm{P}$ $=0.015)$, place of residence $(P=0.04)$, number of brothers $(\mathrm{P}<0.0001)$ and sisiters $(\mathrm{P}=0.007)$, occupation of fathers $(\mathrm{P}=0.03)$ and mothers $(\mathrm{P}=0.023)$, and age of fathers $(\mathrm{P}=$ $0.021)$ and mothers $(P=0.027)$ had a statistically significant diffrence in the two groups.

\section{Discussion}

This study aimed at determining the effects of video gaming on primary monosymptomatic nocturnal enuresis in children with addiction to video gaming. Normally, over five years of age, urination continence should be obtained, yet some children do not achieve this status.

In another study concluded that genes that have the tendency to cause NE are related to the $8 \mathrm{q}, 12 \mathrm{q}$ and $13 \mathrm{q}$ chromosomes (19); this issue was not investigated by the current study. Other studies reported that family history of children indicated $22 \%$ to $48 \%$ genetic basis for voiding dysfunction $(6,20)$. In a study by Yousefichaijan et al., birth order, education level of the family, economical status, male gender, and history of urinary infection were reported to be related to primary monosymptomatic nocturnal enuresis (21); this was also seen in the current study. Since some studies have shown no differences in the demographic characteristics between the two groups (5), yet a statistically significant difference was found in demographic characteristics. Carotenuto et al. in their study found that etiology and pathogenesis of primary monosymptomatic nocturnal enuresis is multi-factorial, and it is believed that more than one factor affects each patient (22). Also in similar studies, in was indicated that regulating mechanisms of BP may play a role in the pathophysiology of nocturnal enuresis. Based on these, they proposed that children with enuresis had a higher nocturnal BP compared to healthy individuals $(14,23)$. Some studies have shown that nocturnal enuresis decreases with age (24). The current study showed the same results, with a peak incidence at seven years, which might be an accidental finding. Other studies suggested that males are three times more likely to wet their beds than females (25); the current study showed a male to female predominance yet this was equal in case and control groups (24), and there was a higher incidence of obesity in the case group and this was significant.

The limitation of this study was incomplete questionnaires provided by parents yet after explaining to parents about effect of nocturnal enuresis on urinary and other body systems they agreed to cooperate in the study. As a limitation, the researchers did not consider severity of enuresis. Furthermore, it is recommended to confirm 


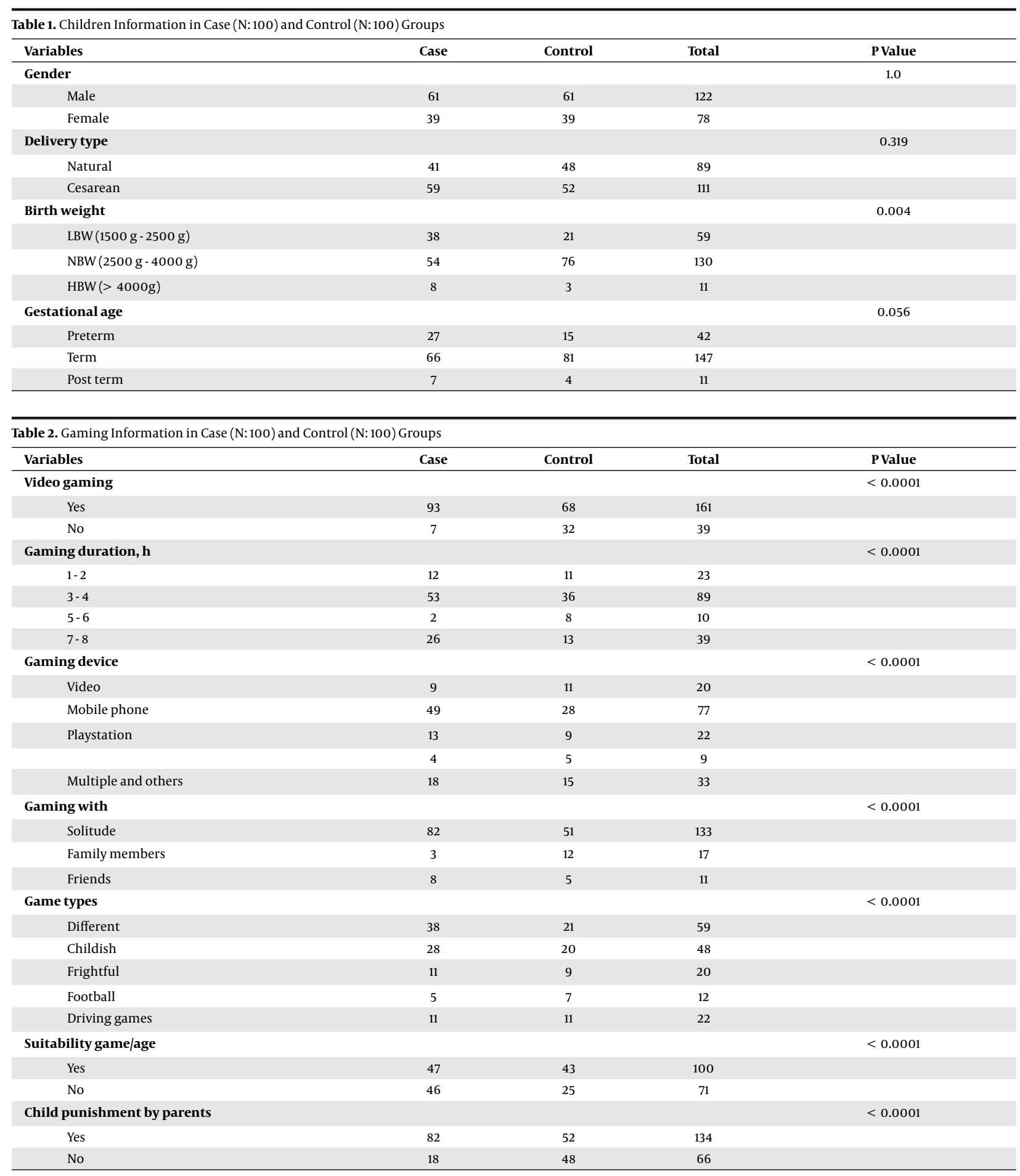

these findings by further studies with attention to enuresis severity factors.

Nephro-Urol Mon. 2018;10(3):e67291.

\subsection{Conclusion}

Healthy children compared to children with primary monosymptomatic nocturnal enuresis had better status in video gaming and familial aspects, and thus primary 
monosymptomatic nocturnal enuresis can be reduced by control of these stressful factors.

\section{Acknowledgments}

The authors gratefully acknowledge the research council of Arak University of Medical Sciences (Grant No.2122) for their financial support.

\section{Footnotes}

Conflicts of Interest: The authors declared no competing interests.

Funding/Support: Arak University of Medical Sciences funded this study.

\section{Implication for Health Policy Mak-} ers/Practice/Research/Medical Education: Addiction to video gaming was more common in children with primary monosymptomatic nocturnal enuresis compared to healthy children. This can be due to more stress in children with addiction to video gaming.

\section{References}

1. Butler RJ, Heron J. The prevalence of infrequent bedwetting and nocturnal enuresis in childhood. A large British cohort. Scand J Urol Nephrol. 2008;42(3):257-64. doi: 10.1080/00365590701748054. [PubMed: 18432533].

2. Yousefichaijan P, Rezagholizamenjany M, Rafiei F, Taherahmadi H, Rafiei M. The relationship between blood biomarkers level and the prognosis of nephrotic syndrome in the children. Int J Pediatr. 2016;4(9):3489. doi: 10.22038/ijp.2016.7302.

3. Augner C, Hacker GW. Associations between problematic mobile phone use and psychological parameters in young adults. Int J Public Health. 2012;57(2):437-41. doi: 10.1007/s00038-011-0234-z. [PubMed: 21290162]

4. Yeung CK, Sreedhar B, Sihoe JD, Sit FK, Lau J. Differences in characteristics of nocturnal enuresis between children and adolescents: a critical appraisal from a large epidemiological study. BJU Int. 2006;97(5):1069-73. doi: 10.1111/j.1464-410X.2006.06074.x. [PubMed: 16643494].

5. Franco I, von Gontard A, De Gennaro M, International Childrens's Continence S. Evaluation and treatment of nonmonosymptomatic nocturnal enuresis: a standardization document from the International Children's Continence Society. J Pediatr Urol. 2013;9(2):234-43. doi:10.1016/j.jpurol.2012.10.026. [PubMed: 23260268].

6. Ozden C, Ozdal OL, Altinova S, Oguzulgen I, Urgancioglu G, Memis A. Prevalence and associated factors of enuresis in Turkish children. Int Braz J Urol. 2007;33(2):216-22. [PubMed: 17488542].

7. Tai HL, Chang YJ, Chang SC, Chen GD, Chang CP, Chou MC. The epidemiology and factors associated with nocturnal enuresis and its severity in primary school children in Taiwan. Acta Paediatr. 2007;96(2):242-5. [PubMed: 17429913]

8. Khaleghipour S, Masjedi M, Kelishadi R. The effect of breathing exercises on the nocturnal enuresis in the children with the sleep-disordered breathing. Iran Red Crescent Med J. 2013;15(11). e8986. doi: 10.5812/ircmj.8986. [PubMed: 24719691]. [PubMed Central: PMC3971783].
9. Schutz-Fransson U, Kurol J. Rapid maxillary expansion effects on nocturnal enuresis in children: a follow-up study. Angle Orthod. 2008;78(2):201-8. doi: 10.2319/021407-71.1. [PubMed: 18251602].

10. Waleed FE, Samia AF, Samar MF. Impact of sleep-disordered breathing and its treatment on children with primary nocturnal enuresis. Swiss Med Wkly. 2011;141:W13216. doi: 10.4414/smw.2011.13216. [PubMed: 21720969].

11. Yousefi P, Firouzifar M, Cyrus A. Correlation between sacral ratio and primary enuresis. J Nephropathol. 2012;1(3):183-7. doi: 10.5812/nephropathol.8120. [PubMed: 24475413]. [PubMed Central: PMC3886147].

12. Safarinejad MR. Prevalence of nocturnal enuresis, risk factors, associated familial factors and urinary pathology among school children in Iran. J Pediatr Urol. 2007;3(6):443-52. doi: 10.1016/j.jpurol.2007.06.001. [PubMed: 18947792].

13. Yousefichaijan P, Dorreh F, Abbasian L, Pakniyat AG. Assessing the prevalence distribution of abnormal laboratory tests in patients with simple febrile seizure. J Pediatr Neurosci. 2015;10(2):93-7. doi: 10.4103/1817-1745.159180. [PubMed: 26167207]. [PubMed Central: PMC4489076].

14. Wang QW, Wen JG, Song DK, Su J, Zhu QH, Liu K, et al. Bed-wetting in Chinese children: epidemiology and predictive factors. Neurouro Urodyn. 2007;26(4):512-7. doi: 10.1002/nau.20373. [PubMed: 17315220].

15. De Sousa A, Kapoor H, Jagtap J, Sen M. Prevalence and factors af fecting enuresis amongst primary school children. Indian J Urol. 2007;23(4):354-7. doi: 10.4103/0970-1591.36703. [PubMed: 19718287] [PubMed Central: PMC2721563]

16. Young $\mathrm{K}$. Understanding online gaming addiction and treatment issues for adolescents. Am J Fam Ther. 2009;37(5):355-72. doi: $10.1080 / 01926180902942191$.

17. Ng BD, Wiemer-Hastings P. Addiction to the Internet and online gaming. Cyberpsychol Behav. 2005;8(2):110-3. doi: 10.1089/cpb.2005.8.110.

18. Mehroof M, Griffiths MD. Online gaming addiction: the role of sensation seeking, self-control, neuroticism, aggression, state anxiety, and trait anxiety. Cyberpsychol Behav Soc Netw. 2010;13(3):313-6. doi: 10.1089/cyber.2009.0229. [PubMed: 20557251].

19. Kalorin CM, Mouzakes J, Gavin JP, Davis TD, Feustel P, Kogan BA. Tonsillectomy does not improve bedwetting: Results of a prospective controlled trial. J Urol. 2010;184(6):2527-32. doi: 10.1016/j.juro.2010.08.040

20. Yousefichaijan $\mathrm{P}$, Rezagholizamenjany $\mathrm{M}$, Dorreh $\mathrm{F}$, Shariatmadari F, Ghandi Y, Alinejad S, et al. Serum vitamin D status in reflux nephropathy. Sch J App Med Sci. 2016;4(12):4325-7. doi: 10.21276/sjams.2016.4.12.34

21. Yousefichaijan P, Dorreh F, Rafiei M, Nouri-Kopaei S, Shariatmadari F, Pakniyat A, et al. Effect of movement and developmental factors in growth and evolution in children with vesicoureteral reflux. $J$ Renal Inj Prev. 2015;4(3):96-100. doi: 10.12861/jrip.2015.19. [PubMed: 26468482]. [PubMed Central: PMC4594221].

22. Carotenuto M, Esposito M, Pascotto A. Facial patterns and primary nocturnal enuresis in children. Sleep Breath. 2011;15(2):221-7. doi 10.1007/s11325-010-0388-6. [PubMed: 20607423].

23. Dhondt K, Raes A, Hoebeke P, Van Laecke E, Van Herzeele C, Vande Walle J. Abnormal sleep architecture and refractory nocturnal enuresis. J Urol. 2009;182(4 Suppl):1961-5. doi: 10.1016/j.juro.2009.05.103. [PubMed: 19695632].

24. Weintraub Y, Singer S, Alexander D, Hacham S, Menuchin G, Lubetzky $\mathrm{R}$, et al. Enuresis-an unattended comorbidity of childhood obesity. Int J Obes (Lond). 2013;37(1):75-8. doi: 10.1038/ijo.2012.108. [PubMed: 22828939].

25. Inan M, Tokuc B, Aydiner CY, Aksu B, Oner N, Basaran UN. Personal characteristics of enuretic children: an epidemiological study from South-East Europe. Urol Int. 2008;81(1):47-53. doi: 10.1159/000137640. [PubMed: 18645271]. 
Table 3. Children Families Status in Case (N:100) and Control (N:100) Groups

\begin{tabular}{|c|c|c|c|c|}
\hline Variables & Case & Control & Total & P Value \\
\hline Father education & & & & 0.005 \\
\hline Ph. D & 2 & 1 & 3 & \\
\hline Master & 8 & 4 & 12 & \\
\hline Bachelor & 28 & 17 & 45 & \\
\hline Diploma & 50 & 43 & 93 & \\
\hline Under diploma & 5 & 19 & 24 & \\
\hline Mother education & & & & 0.001 \\
\hline Ph.D & 4 & 2 & 6 & \\
\hline Master & 8 & 7 & 15 & \\
\hline Associate & 6 & 18 & 24 & \\
\hline Diploma & 50 & 46 & 96 & \\
\hline Under diploma & 8 & 20 & 28 & \\
\hline
\end{tabular}

Economical status, Million IRR

0.015

\begin{tabular}{|cccc}
$<5$ & 1 & 0 & 1 \\
\hline $5-10$ & 17 & 30 & 47 \\
\hline $10-15$ & 39 & 48 & 87 \\
\hline $15-20$ & 34 & 17 & 51 \\
$>20$ & 9 & 5 & 14
\end{tabular}

Living area

\begin{tabular}{|lccc|}
\hline Downtown & 36 & 18 & 54 \\
\hline Fringe & 55 & 71 & 127 \\
\hline Rural & 9 & 11 & 20 \\
\hline
\end{tabular}

Brothers number

\begin{tabular}{llll}
0 & 38 & 63 & 101 \\
1 & 32 & 33 & 65 \\
\hline 2 & 30 & 4 & 34
\end{tabular}

Sisters number

0.04

$\begin{array}{llcl}0 & 53 & 64 & 117 \\ 1 & 34 & 34 & 67 \\ \geq 2 & 33 & 2 & 16\end{array}$

Father occupation

$<0.0001$

\begin{tabular}{|c|c|c|c|c|}
\hline Self employment & 22 & 36 & 58 & \\
\hline Employee & 64 & 41 & 105 & \\
\hline Worker & 11 & 22 & 33 & \\
\hline Workless & 3 & 1 & 4 & \\
\hline Mother occupation & & & & 0.023 \\
\hline Housekeeper & 63 & 79 & 142 & \\
\hline
\end{tabular}




\begin{tabular}{|c|c|c|c|c|}
\hline Employee & 34 & 17 & 51 & \\
\hline Self employment & 3 & 4 & 7 & \\
\hline Father age, $y$ & & & & 0.021 \\
\hline$<25$ & 1 & 1 & 2 & \\
\hline $26-30$ & 38 & 17 & 55 & \\
\hline $31-35$ & 36 & 44 & 80 & \\
\hline $36-40$ & 19 & 29 & 48 & \\
\hline$>40$ & 6 & 9 & 15 & \\
\hline Mother age, y & & & & 0.027 \\
\hline$<25$ & 8 & 10 & 18 & \\
\hline $26-30$ & 44 & 34 & 78 & \\
\hline $31-35$ & 31 & 44 & 75 & \\
\hline $36-40$ & 17 & 8 & 25 & \\
\hline$>40$ & 0 & 4 & 4 & \\
\hline
\end{tabular}

